\title{
Asimilasi Narapidana di Lembaga Pemasyarakatan Terbuka Mataram
}

\author{
Sofian Hadi Sasmita \\ Mahasiswa Program Studi Magister Ilmu Hukum Universitas Mataram \\ Email: rizalpahrur@gmail.com
}

\begin{abstract}
ABSTRAK
Penelitian ini bertujuan untuk membahas mengenai Asimilasi Narapidana Di Lembaga Pemasyarakatan Terbuka Mataram. Isu hukum yang dikemukakan dalam tulisan ini mencakup Bagaimana syarat pemberian asimilasi bagi narapidana dari lapas menuju Lapas Terbuka Mataram. Penelitian ini merupakan penelitian hukum normatif yang mengkaji norma hukum tentang syarat pemberian asimilasi dari lapas menuju lapas terbuka Mataram. Pendekatan yang digunakan adalah pendekatan perundang-undangan dan pendekatan konseptual. Teknik pengumpulan bahan hukum dilakukan melaui studi kepustakaan dengan melakukan pengolahan bahan hukum secara sistematis dan melakukan penafsiran yang dikenal dalam ilmu hukum terhadap peraturan perundang-undangan yang berkaitan dengan penelitian ini dan kesimpulan akhirnya ditarik secara deduktif. Hasil penelitian dalam tulisan ini menyimpulkan bahwa syarat asimilasi bagi narapidana tidaklah sama namun dibedakan berdasarkan tindak pidana yang dilakukan oleh narapidana. Tindak pidana tersebut dikategorikan menjadi dua yaitu tindak pidana secara umum dan tindak pidana secara khusus yang termasuk dalam "kejahatan luar biasa".
\end{abstract}

Kata Kunci: Asimilasi, Narapidana, Lapas Terbuka

\section{ABSTRACT}

The research aims to discuss Assimilation of Prisoners in Mataram Open Correctional Institution. The legal issue proposed in this research include How is the provision of assimilation for prisoners from prisons to the Mataram Open Correctional Institution. This study used normative legal research that examines the legal norms regarding the provision of assimilation from prisons to open prisons and stages of assimilation in the Mataram Open Correctional Institution. The approach of the thesis used legislation and conceptual approach. The technique of collecting legal materials are (1) literature study by systematically processing the legal material and (2) making known interpretations in law science to the laws and regulations relating to this research and the conclusion ultimately drawn deductively. The result of this script concludes that the assimilation requirement for prisoners is not the same but differentiated based on criminal acts committed by prisoners. The criminal acts are categorized into general crimes and special crimes which are included in "extraordinary crimes".

Keywords: Assimilation, Prisoner, Open Correctional Institution 


\section{A. PENDAHULUAN}

Lembaga pemasyarakatan yang merupakan bagian dari sistem peradilan pidana, bukan saja sebagai tempat untuk semata-mata memidana orang, melainkan juga sebagai tempat untuk membina atau mendidik orang-orang terpidana, agar mereka itu setelah selesai menjalankan pidana mereka, mempunyai kemampuan untuk menyesuaikan diri dengan kehidupan di luar lembaga pemasyarakatan sebagai warganegara yang baik dan taat pada hukum yang berlaku. 1

Salah satu proses pembinaan di Lembaga Pemasyarakatan (Lapas) adalah asimilasi. Di dalam Pasal 14 huruf j Undang-Undang Nomor 12 Tahun 1995 Tentang Pemasyarakatan menyebutkan bahwa asimilasi merupakan salah satu hak yang dapat diperoleh narapidana. Asimilasi ini diberikan kepada narapidana apabila telah memenuhi persyaratan yaitu, telah berkelakuan baik, dapat mengikuti program pembinaan dengan baik, dan telah menjalani $1 / 2$ (setengah) masa pidananya. Asimilasi merupakan proses pembinaan warga binaan pemasyarakatan di luar LAPAS (ekstemural). 2

Proses pembinaan ini dilakukan dengan membaurkan narapidana dengan masyarakat. Maksud dan tujuan asimilasi ini adalah mempersiapkan narapidana untuk kembali menjalani kehidupan bermasyarakat yang baik. Dalam rangka mempersiapkan narapidana kembali berintegrasi dengan masyarakat, maka dibentuklah Lembaga Pemasyarakatan Terbuka (Lapas Terbuka). Pasal 38 ayat (1) Peraturan Pemerintah Nomor 32 Tahun 1999 Tentang Syarat dan Tata Cara Pelaksanaan Hak Warga Binaan Pemasyarakatan meyebutkan bahwa Lapas

\footnotetext{
1 Sahardjo, Pohon Beringin Pengayoman, Sukamiskin, Bandung, 1964, hlm. 15.

${ }^{2}$ Pembinaan warga binaan pemasyarakatan di Lapas dilaksanakan secara intramural (di dalam Lapas) dan secara ekstemural (di luar Lapas) lihat dalam Penjelasan Pasal 6 ayat (1) Undang-Undang Nomor 12 Tahun 1995 Tentang Pemasyarakatan.
}

Terbuka merupakan salah satu tempat untuk melaksanakan asimilasi. Lapas Terbuka merupakan suatu institusi baru di lingkungan Direktorat Jenderal Pemasyarakatan Kementerian Hukum dan Hak Asasi Manusia. Keberadaan Lapas Terbuka di Indonesia pada awalnya hanya ada 6 (enam), yaitu; Lapas Terbuka klas II B Pasaman, Jakarta, Kendal, Nusa Kambangan, Mataram, dan Waikabubak. Pembentukan Lapas Terbuka ini merupakan implementasi dari Surat Keputusan Menteri Hukum dan Ham Republik Indonesia Nomor: M.03.PR.0703 Tahun 2003 Tertanggal 16 April 2003.3

Upaya mengintegrasikan narapidana dengan masyarakat pada Lapas Terbuka terlihat dengan berdekatannya lingkungan pembinaan dengan lingkungan masyarakat tanpa adanya tembok atau jeruji pembatas sebagaimana Lapas Tertutup atau Rumah Tahanan (Rutan). Melalui Lapas Terbuka tersebut narapidana berinteraksi dan berkomunikasi secara langsung dengan masyarakat sekitarnya. Hal ini menunjukkan terjadinya suatu perubahan dinamis dalam bidang hukum pidana menyangkut dengan perlakuan terhadap seseorang yang melakukan kejahatan menuju bentuk modern dalam sistem hukum pidana Indonesia.4

Tidak semua narapidana dapat melaksanakan asimilasi pada Lapas Terbuka karena ada syarat-syarat yang harus dipenuhi sebelumnya. Bagi narapidana tindak pidana terorisme, narkotika, dan prekursor narkotika, psikotropika, korupsi, kejahatan terhadap keamanan negara dan kejahatan hak asasi manusia yang berat, serta kejahatan transnasional terorganisasi termasuk kedalam kategorisasi kejahan luar biasa

\footnotetext{
Tholib, Pemberdayaan Lapas Terbuka Sebagai Wujud Pelaksanaan Community Based Corrections Di Indonesia, Dikutip dari http://www.ditjenpas.go.id, Diakses pada Tanggal $11 \mathrm{Mei}$ 2016.

4 Hamid Awaludin, dalam kata sambutan peresmian LAPAS Terbuka Jakarta, Dikutip dari http://www. Kompas.co.id/news/16/05/06, Diakses pada Tanggal 11 Mei 2016.
} 
tidak bisa melaksanakan asimilasi di Lapas Terbuka.

Pengetatan persyaratan tersebut lebih lanjut diatur dalam Peraturan Menteri Hukum dan Hak Asasi Manusia Nomor 21 Tahun 2013 tentang Syarat dan tata Cara Pemberian Remisi, Asimilasi, Cuti Mengunjungi Keluarga, Pembebasan Bersyarat, Cuti Menjelang Bebas, dan Cuti Bersyarat (Permen No. 21 Tahun 2013)

Guna mengetahui secara mendalam mengenai hal tersebut di atas maka penulis tertarik untuk melakukan penelitian dengan judul "Asimilasi Narapidana Di Lembaga Pemasyarakatan Terbuka Mataram". Sehingga peneliti dapat mengetahui sejauh mana aktualisasi norma yang mengatur tentang asimilasi di Indonesia.

\section{B. PEMBAHASAN}

\section{Syarat Asimilasi}

\section{a. Syarat Asimilasi Secara Umum}

Syarat ini harus dipenuhi oleh narapidana pada umumnya artinya syarat yang harus dipenuhi oleh seseorang narapidana baik narapidana yang dikategorikan kedalam tindak pidana kejahatan yang luar biasa maupun narapidana dengan tindak pidana umum lainnya.

Syarat-syarat tersebut yaitu:

\section{1) Berkelakuan Baik;}

Seseorang narapidana sebelum diberikan program asimilasi maka akan diamati dan dinilai perilakunya dalam pergaulannya dengan sesama narapidana atau penghuni lainnya maupun dengan petugas lapas itu sendiri. Baik buruknya perilaku seseorang narapidana di dalam lapas akan berpengaruh terhadap pembinaanya. Perilaku ini menjadi sangat penting mengingat program pembinaan asimilasi dilaksanakan ditengah-tengah masyarakat.

Dalam Permen No. 21 Tahun 2016, Pasal 1 angka 17 menerangkan "Berkelakuan baik adalah tidak sedang menjalani hukuman disiplin yang tercatat dalam buku register $\mathrm{F}$ dan telah mengikuti program pembinaan yang diselenggarakan di Lapas atau LPKA dengan predikat baik". Syarat berkelakuan baik ini harus dibuktikan dengan tidak sedang menjalani hukuman disiplin dalam kurun waktu 6 (enam) bulan terakhir, terhitung sejak tanggal pemberian asimilasi (Lihat Pasal 21 ayat (3) Permen 21 Tahun 2013).

\section{2) Aktif Mengikuti Program Pembinaan Dengan Baik;}

Pasal 1 ayat (1) Peraturan Pemerintah No. 31 Tahun 1999 tentang Pembinaan dan Pembimbingan Warga Binaan Pemasyarakatan disebutkan bahwa "Pembinaan adalah kegiatan untuk meningkatkan kualitas ketaqwaan kepada Tuhan Yang Maha Esa, intelektual, sikap dan perilaku, profesional, kesehatan jasmani dan rohani narapidana dan anak didik Pemasyarakatan".

Dalam hal pembinaan terhadap Warga Binaan Pemasyarakatan, Pemerintah mengeluarkan Peraturan Pemerintah Nomor 31 Tahun 1999 tentang Pembinaan dan Pembimbingan Warga Binaan Pemasyarakatan. PP No.31 Tahun 1999 ini merupakan peraturan pelaksanaan dari UU No.12 Tahun 1995 tentang Pemasyarakatan.

Berdasarkan ketentuan tersebut maka program pembinaan warga binaan pemasyarakatan di Lembaga Pemasyarakatan ditekankan pada kegiatan pembinaan kepribadian seperti menyadari kesalahannya, dapat memperbaiki diri, dan tidak mengulangi tindak pidana sehingga dapat diterima kembali oleh lingkungan masyarakat. Adapun pembinaan kemandirian diarahkan pada pembinaan bakat dan keterampilan agar warga binaan pemasyarakatan dapat berperan kembali menjadi warga masyarakat yang bebas dan bertanggung jawab.

Begitu pentingnya pembinaan kepribadian dan pembinaan kemandirian bagi narapidana sebagai bekal setelah bebas nantinya, namun yang tidak kalah 
[Vol. 32 No.1, Maret 2017]

[JATISWARA

Gurnal Meme Hukum]

penting juga adalah peran aktif narapidana untuk mengikuti kegiatan tersebut. Bagaimanapun bagusnya program pembinaan kalau narapidana tidak mau mengikuti dengan baik maka hasilnya tidak akan maksimal pula. Harapan untuk mengembalikan hubungan sosialnya dengan masyarakat tentunya akan tidak bermakna. Max Weber berpendapat bahwa "ciri yang mencolok dari hubungan sosial adalah kenyataan bahwa hubunganhubungan tersebut bermakna bagi mereka yang mengambil bagian di dalamnya."5 Peran aktif narapidana dalam mengikuti program pembinaan dengan baik sangatlah dibutuhkan karena narapidana sudah tidak lagi dianggap sebagai objek tapi sebagai subjek pembinaan sebagai ciri dari sistem pemasyarakatan.

Narapidana diberikan kesempatan untuk menyalurkan bakat, minat dan keterampilannya melalui kegiatan-kegiatan pembinaan yang telah diprogramkan. Hal ini dapat kita lihat dengan diadakannya "Napi Craft" pameran hasil karya narapidana yang dilaksanakan hampir setiap tahun sejak tahun 2012. "Pelaksanaan "Napi Craft 2012" lalu yang bertajuk "We care" mendapatkan perhatian besar dari banyak kalangan. ...ternyata mampu membangkitkan semangat warga binaan untuk berkarya lebih baik dan menjadi sesuatu yang kemudian secara positif telah menghadirkan perubahan sikap, mental, serta spiritual warga binaan."

Perhatian dan peran serta masyarakat dalam proses pembinaan narapidana sangatlah dibutuhkan. Hal ini mengingat bahwa masyarakat adalah tempat kembali bagi narapidana untuk menjalani kehidupan sehari-hari setelah bebas nantinya. Penerimaan masyarakat terhadap narapidana serta pengakuan terhadap potensi-potensi positif yang dimiliki oleh

5 Didin Sudirman, Sosiologi Penjara; Buku Materi Kuliah Akademi Ilmu Pemasyarakatan, Jakarta, 2003, hlm. 17.

${ }^{6}$ Napi Craft 2013 Terampil dan Berhasil, Warta Pemasyarakatan Nomor: 55 Tahun XIV/2013, hlm. 12. narapidana dapat menumbuhkan kepercayaan diri narapidana. Bagaimanapun juga narapidana adalah manusia yang merupakan bagian dari masyarakat yang perlu diakui keberadaanya. Malinosky dalam Didin Sudirman mengatakan bahwa "Dalam banyak peristiwa yang dapat dibuktikan, orang primitif yang telah melanggar norma yang penting melakukan bunuh diri, karena mereka tidak dapat menanggung hukuman yang berwujud penolakan masyarakat."7 Untuk itu peran aktif dari Petugas Pembina (Petugas Pemasyarakatan) dan perhatian maupun dukungan dari pemerintah daerah maupun masyarakat sangatlah menentukan keberhasilan pembinaan narapidana itu sendiri.

\section{3) Telah Menjalani $1 / 2$ (setengah) Masa Pidana}

Narapidana yang menjalani pidana di dalam lembaga pemasyarakatan tentunya akan menjalani hari-harinya menurut ketentuan yang telah diatur oleh lapas dalam peraturan tata tertib lapas, sejak pertama menjalani pidana sampai dengan bebas sesungguhnya. Bagi narapidana yang telah berkelakuan baik dan aktif mengikuti pembinaan dengan baik tentunya akan dipersiapkan untuk program pembinaan selanjutnya. Tidak selamanya narapidana berada di dalam lapas untuk menjalani pidananya. Mereka (narapidana) dapat diberikan kesempatan untuk bersosialisasi dan berasimilasi dengan masyarakat luar. Hal ini sebagaimana tertuang dalam salah satu prinsip pemasyarakatan yang menghendaki narapidana tidak diasingkan dari masyarakat. Selama kehilangan kemerdekaannya, narapidana harus dikenalkan dengan masyarakat dan tidak boleh diasingkan daripadanya. Prinsip ini menghendaki narapidana tidak terisolasi di dalam tembok penjara, serta narapidana harus melakukan kontak dengan masyarakat luar.

Narapidana yang telah menjali $1 / 2$ (setengah) dari masa pidananya

${ }^{7}$ Didin Sudirman, op.cit, hlm. 143. 
mempunyai kesempatan

untuk

berasimilasi. Artinya apabila seorang narapidana dipidana selama 4 (empat) tahun maka setelah menjalani 2 (dua) tahun dikurangi dengan total remisi, maka ia dapat diberikan kesempatan asimilasi.

Asimilasi itu sendiri terbagi atas dua, yaitu: Pertama, asimilasi kedalam lembaga pemasyarakatan, yang bentuknya berupa kunjungan dari keluarga maupun masyarakat; Kedua, asimilasi keluar lembaga pemasyarakatan, seperti cuti mengunjungi keluarga. Cuti ini diberikan sebagai upaya memelihara kerukunan rumah tangga, berupa kesempatan berkumpul bersama di tempat kediaman keluarga dalam jangka waktu dua hari ( $2 \mathrm{x}$ 24 jam) di luar waktu perjalanan. ${ }^{8}$

Asimilasi ini secara langsung di pengaruhi Pasal 15 dan 16 KUHP.

Pasal 15 KUHP, Berbunyi :

(1) Jika terpidana telah menjalani dua pertiga dari lamanya pidana penjara yang dijatuhkan kepadanya, yang sekurang-kurangnya harus sembilan bulan, maka ia dapat dikenakan pelepasan bersyarat. Jika terpidana harus menjalani beberapa pidana berturut-turut, pidana itu dianggap sebagai satu pidana.

(2) Ketika memberikan pelepasan bersyarat, ditentukan pula suatu masa percobaan, serta ditetapkan syaratsyarat yang harus dipenuhi selama masa percobaan.

(3) Masa percobaan itu lamanya sama dengan sisa waktu pidana penjara yang belum dijalani, ditambah satu tahun. Jika terpidana ada dalam tahanan yang sah, maka waktu itu tidak termasuk masa percobaan.

Lebih lanjut Pasal 16 KUHP menyebutkan bahwa;

\footnotetext{
${ }^{8}$ Petrus Irwan Panjaitan dan Chairijah, Pidana Penjara Dalam Perspektif Penegak Hukum, Masyarakat dan Naraidana, IHC, Jakarta, 2008. Hlm, 40-41. Hlm, 48
}

(1) Ketentuan pelepasan bersyarat ditetapkan oleh Menteri Kehakiman atas usul atau setelah mendapat kabar dari pengurus penjara tempat terpidana, dan setelah mendapat keterangan dari Jaksa tempat asal terpidana. Sebelum menentukan, harus bertanya dulu pendapat Dewan Reklasering Pusat, yang tugasnya diatur oleh Menteri Kehakiman.

(2) Ketentuan mencabut pelepasan bersyarat, begitu juga hal-hal yang tersebut dalam Pasal 15a ayat (5) KUHP, ditetapkan oleh Menteri Kehakiman atas usul dan setelah mendapat kabar dari Jaksa tempat asal terpidana. Sebelum memutus, harus ditanya dahulu pendapat Dewan Reklasering Pusat.

(3) Selama pelepasan bersyarat masih dapat dicabut, maka atas perintah jaksa setempat dimana dia berada, orang yang dilepaskan bersyarat dapat ditahan guna menjaga ketertiban umum, jika ada sangkaan yang beralasan bahwa orang itu selama masa percobaan telah berbuat hal-hal yang melanggar syarat-syarat tersebut dalam surat pasnya. Jaksa harus segera memberitahukan penahan itu kepada Menteri Kehakiman.

(4) Waktu penahanan paling lama 60 (enam puluh) hari. Jika penahanan disusul dengan penghentian untuk sementara waktu atau pencabutan pelepasan bersyarat, maka orang itu dianggap meneruskan menjalani pidananya mulai hari ditahan.

Melihat ketentuan Pasal 15 dan Pasal 16 KUHP tersebut, maka penulis berpendapat bahwa kententuan mengenai syarat asimilasi yaitu harus telah menjalani $1 / 2$ (setengah) masa pidana sudah tepat. Hal ini mengingat bahwa apabila telah menjalani 2/3 (dua per tiga) masa pidana maka narapidana dapat diberikan pelepasan bersyarat. Dengan diberikannya kesempatan berasimilasi pada saat telah menjalani $1 / 2$ (setengah) masa pidana maka 
diharapkan narapidana telah siap secara mental untuk kembali berintegrasi dengan masyarakat. Pada saat melaksanakan asimilasi narapidana diharapkan mampu menyerap nilai-nilai kehidupan positif yang ada di dalam masyarakat. Selain itu narapidana juga bisa mengikuti kegiatan pembinaan yang bersifat produktif.

\section{4) Telah Membayar Lunas Denda dan atau Uang Pengganti;}

Ketentuan mengenai keharusan untuk membayar lunas denda dan/atau uang pengganti ini dicantumkan dalam Pasal 23 ayat (1) Permen No. 21 Tahun 2016 yang mensyaratkan bahwa "Asimilasi dapat diberikan kepada Narapidana setelah membayar lunas denda dan/atau uang pengganti sesuai dengan putusan pengadilan." Selanjutnya di dalam ayat (2) menentukan bahwa "Dalam hal Narapidana sebagaimana dimaksud pada ayat (1) tidak dapat membayar lunas denda dan/atau uang pengganti, Narapidana wajib menjalani pidana kurungan dan/atau penjara pengganti sesuai dengan ketentuan peraturan perundang-undangan." Dalam ayat (3) lebih ditekankan lagi mengenai keharusan membayar lunas denda dan/atau uang pengganti terhadap narapidana tindak pidana korupsi. Pasal 23 ayat (3) menentukan "Bagi Narapidana yang dipidana karena melakukan tindak pidana korupsi dapat diberikan Asimilasi setelah membayar lunas denda dan/atau uang pengganti."

Keharusan untuk membayar lunas denda dan/atau uang pengganti sebagai salah satu syarat untuk bisa melaksanakan asimilasi dipengaruhi oleh Pasal 10 KUHP dimana Pidana Denda merupakan bagian dari Pidana Pokok. Dalam Pasal 10 KUHP telah ditentukan mengenai jenis sanksi pidana yaitu pidana pokok dan pidana tambahan. Pidana denda sendiri masuk kedalam kategori jenis pidana pokok. Pidana denda selain diancamkan pada pelaku pelanggaran juga diancamkan terhadap kejahatan yang adakalanya sebagai alternatif atau kumulatif. $^{10}$ Selanjutnya dalam Pasal 30 KUHP ditentukan mengenai besaran denda, kurungan pengganti denda maupun lama kurungan pengganti denda.

Asimilasi tidak dapat dijadikan alasan penghapus pidana (pidana denda) bagi narapidana yang dipidana denda untuk tidak memenuhi kewajibannya membayar denda atau menjalani kurungan pengganti denda sesuai dengan putusan pengadilan. Sebagaimana kita ketahui bahwa alasan pemaaf maupun alasan pembenar yang diatur dalam KUHP berlaku sebelum putusan pengadilan. Untuk mengingatkan kita bahwa hal-hal yang masuk dalam alasan Pembenar yaitu: keadaan darurat/daya paksa (Pasal 48); pembelaan terpaksa (Pasal 49 ayat 1); menjalankan peraturan perundang-undangan (Pasal 50); dan menjalankan perintah jabatan yang sah (Pasal 51 ayat 1). Selanjutnya untuk alasan Pemaaf yaitu: tidak mampu bertanggungjawab (Pasal 44); daya paksa (Pasal 48); pembelaan terpaksa melampaui batas (Pasal 49 ayat 2); dan menjalankan perintah jabatan yang sah (Pasal 51 ayat 2). ${ }^{11}$

Lebih lanjut mengenai hal ini I Gede Widhiana Suarda menjelaskan bahwa:

"Alasan penghapus pidana setelah putusan pengadilan yang terdapat dalam KUHP adalah meninggalnya terpidana (Pasal 83) dan daluwarsa (Pasal 84 ayat 1) Sedangkan yang terdapat di luar KUHP adalah karena pemberian grasi dan amnesty oleh Presiden."12

Untuk itu pentingnya asimilasi bagi narapidana tidak mengesampingkan pidana denda yang menyertai pidana penjara. Syarat ini menjadi sangat logis mengingat pelaksanaan asimilasi berada diluar lapas atau ditengah-tengah masyarakat. Dapat

\footnotetext{
10 Leden Marpaung, Asas - Teori - Praktik Hukum Pidana, Cetakan Ke-6, Sinar Grafika, Jakarta, 2009, hlm. 109.

11 I Gede Widhiana Suarda, Hukum Pidana: Materi Penghapus, Peringan dan Pemberat Pidana, Cetakan Ke-2, Bayumedia Publishing, Malang, 2012, hlm. 160 .

${ }^{12}$ Ibid,
} 
dikatakan pula bahwa hal ini sebagai langkah antisipatif kaburnya narapidana sebelum memenuhi kewajiban untuk membayar pidana denda, sehingga untuk kepentingan keamanan dan guna menjamin pidana yang dijatuhkan berdasarkan putusan pengadilan dijalankan oleh terpidana (narapidana) maka asimilasi tidak diberikan bagi mereka yang tidak membayar lunas denda dan/atau uang pengganti.

\section{b. Syarat Asimilasi Secara Khusus;}

Bagi narapidana tertentu, selain harus memenuhi persyaratan asimilasi secara umum sebagaimana telah diuraikan sebelumnya, maka harus pula memenuhi syarat tambahan (khusus). Syarat-syarat khusus tersebut berlaku bagi narapidana dengan tindak pidana terorisme, narkotika dan prekursor narkotika, psikotropika, korupsi, kejahatan terhadap keamanan negara dan kejahatan hak asasi manusia yang berat, serta kejahatan transnasional terorganisir lainnya. Tindak pidana tersebut dikategorikan ke dalam kejahatan yang luar biasa (ekstra ordinary crime) sehingga memerlukan penanganan khusus. Dianggap sebagai kejahatan yang luar biasa karena mengakibatkan kerugian yang besar bagi negara atau masyarakat atau korban yang banyak atau menimbulkan kepanikan, kecemasan, atau ketakutan yang luar biasa kepada masyarakat. ${ }^{13}$ Untuk itu dalam tulisan ini, narapidana yang dikategorikan dalam kejahatan yang luar biasa tersebut selanjutnya disebut "narapidana tindak pidana khusus".

Dalam memperoleh kesempatan asimilasi, narapidana tindak pidana khusus tersebut diberlakukan syarat yang lebih ketat dibandingkan dengan narapidana tindak pidana lainnya. Syarat-syarat tersebut sebagaimana uraian berikut.

\section{1) Telah Menjalani $2 / 3$ (dua per tiga) Masa Pidana;}

Berbeda dengan narapidana tindak

13 Lihat konsideran Menimbang point a, Peraturan Pemerintah Republik Indonesia Nomor 99 Tahun 2012. pidana umum lainnya yang bisa memperoleh kesempatan berasimilasi setelah menjalani $1 / 2$ (setengah) masa pidananya, maka bagi narapidana tindak pidana khusus harus telah menjalani $2 / 3$ (dua per tiga) masa pidananya. Hal ini sebagaimana disyaratkan dalam Permen No. 21 Tahun 2013.

Pasal 22 ayat (1) Permen No. 21 Tahun 2013 menyatakan bahwa:

Bagi Narapidana yang dipidana karena melakukan tindak pidana terorisme, narkotika dan prekursor narkotika, psikotropika, korupsi, kejahatan terhadap keamanan negara dan kejahatan hak asasi manusia yang berat, serta kejahatan transnasional terorganisir lainnya, asimilasi dapat diberikan setelah memenuhi syarat:

a. Berkelakuan Baik;

b. aktif mengikuti program pembinaan dengan baik; dan

c. telah menjalani $2 / 3$ (dua per tiga) masa pidana.

\section{2) Syarat Tambahan Bagi Narapidana Terorisme;}

Bagi narapidana kasus terorisme selain harus memenuhi persyaratan umum asimilasi dan persyaratan khusus mengenai 2/3 (dua per tiga) masa pidana maka ada beberapa persyaratan tambahan yang harus dipenuhi untuk bisa asimilasi. Persyaratanpersyaratan tersebut erat kaitannya dengan pembinaan kepribadian narapidana utamanya mengenai pola pikir maupun paham-paham radikal yang ada pada diri narapidana tersebut. Hal ini sebagaimana disyaratkan dalam ketentuan Pasal 22 ayat (2) Permen No. 21 Tahun 2013 yang dijabarkan sebagai berikut:

\section{a) Selesai Mengikuti Program Deradikalisasi;}

Program deradikalisasi merupakan program pembinaan khusus bagi narapidana tindak pidana terorisme. Dalam ketentuan Pasal 1 angka 19 Permen No. 21 Tahun 2016 disebutkan bahwa:

"Program Deradikalisasi adalah 
program pembinaan bagi Narapidana yang melakukan tindak pidana terorisme, dengan tujuan mengurangi atau mereduksi paham radikal atau perilaku kekerasan dan memberikan pengetahuan dalam rangka kehidupan berbangsa dan bernegara."

Program deradikalisasi ini harus diikuti oleh narapidana kasus terorisme. Program ini diselenggarakan oleh Lapas dan/atau oleh Badan Nasional Penanggulangan Terorisme (BNPT). Bagi narapidana kasus terorisme untuk bisa asimilasi maka harus selesai mengikuti Program Deradikalisasi.

Bila melihat persyaratan tersebut maka dapat pula dikatakan bahwa walaupun seorang narapidana kasus terorisme telah menjalani $2 / 3$ (dua per tiga) masa pidananya namun belum selesai mengikuti Program Deradikalisasi tersebut maka dapat dipastikan bahwa narapidana tersebut tidak memenuhi syarat untuk mendapatkan asimilasi. Untuk itu pemerintah dalam hal ini pihak lapas maupun BNPT dalam melaksanakan Program Deradikalisasi tersebut hendaknya memperhatikan masa pidana dari masingmasing narapidana sehingga apa yang menjadi tujuan daripada program tersebut dapat tercapai dengan maksimal.

\section{b) Menyatakan Secara Tertulis Ikrar Kesetiaan Kepada NKRI Bagi Narapidana Berkebangsaan Indonesia;}

Setelah selesai mengikuti Program Deradikalisasi maka bagi narapidana terorisme berkebangsaan Indonesia yang ingin mendapatkan asimilasi harus membuat pernyataan tertulis mengenai ikrar kesetiaan kepada Negara Kesatuan Republik Indonesia (NKRI). Ikrar ini menjadi penting untuk mengetahui keinginan dan kemauan narapidana kembali kepada NKRI. Dengan ikrar ini diharapkan bahwa narapidana betul-betul memahami apa yang diikrarkan sehingga terjadi perubahan pola pikir narapidana dari pemikiran radikal kepada pemikiran yang Pancasila. c) Menyatakan Ikrar Secara Tertulis Untuk Tidak Mengulangi Tindak Pidana Terorisme Bagi Narapidana Terorisme Berkebangsaan Asing.

Berbeda dengan narapidana yang berkebangsaan Indonesia yang menyatakan ikrar secara tertulis mengenai kesetiaan kepada NKRI, maka bagi narapidana terorisme yang berkebangsaan Asing selain harus selesai mengikuti Program Deradikalisasi, maka harus menyatakan secara tertulis ikrar untuk tidak mengulangi tindak pidana terorisme. Sama halnya dengan ikrar yang dibuat oleh narapidana terorisme Warga Negara Indonesia (WNI), ikrar yang dibuat oleh narapidana terorisme Warga Negara Asing bertujuan untuk menyadarkan narapidana tersebut bahwa perbuatan teror yang dilakukan tidak dibenarkan oleh hukum Negara Indonesia maupun hukum Negara lainnya di dunia.

\section{Kelengkapan Dokumen Asimilasi}

Bagi narapidana yang telah memenuhi persyaratan sebagaimana yang telah dijelaskan sebelumnya, maka harus melengkapi dokumen-dokumen tertentu sebagai syarat bisa diberikan asimilasi. Dokumen-dokumen yang disyaratkan tersebut diatur dalam Pasal 24 Permen No. 21 Tahun 2013. Dalam Pasal 24 tersebut diatur mengenai persyaratan kelengkapan dokumen bagi narapidana secara umum dan secara khusus.

\section{a. Secara Umum}

Dokumen-dokumen kelengkapan asimilasi bagi narapidana tindak pidana umum berlaku pula untuk narapidana tindak pidana khusus. Dokumen-dokumen tersebut yaitu:

1) fotokopi kutipan putusan hakim dan berita acara pelaksanaan putusan pengadilan;

2) bukti telah membayar lunas denda dan uang pengganti sesuai dengan putusan pengadilan; 
3) laporan perkembangan pembinaan yang dibuat oleh wali pemasyarakatan atau hasil assesment resiko dan assessment kebutuhan yang dilakukan oleh asesor;

4) laporan penelitian kemasyarakatan yang dibuat oleh Pembimbing Kemasyarakatan yang diketahui oleh Kepala Bapas;

5) Salinan register F dari Kepala lapas;

6) Salinan daftar perubahan dari Kepala Lapas;

7) Surat pernyataan dari Narapidana tidak akan melarikan diri dan tidak akan melakukan perbuatan melanggara hukum;

8) Surat jaminan kesanggupan dari pihak keluarga yang diketahui oleh lurah atau kepala desa atau nama lain yang menyatakan:

1. Narapidana tidak akan melarikan diri dan tidak melakukan perbuatan melanggar hukum; dan

2. Membantu dalam membimbing dan mengawasi Narapidana selama mengikuti program asimilasi.

9) Surat jaminan dari sekolah, instansi pemerintah, atau swasta, dan badan/lembaga sosial keagamaan, yang menjamin untuk membantu dalam membimbing dan mengawasi Narapidana selama mengikuti program Asimilasi.

\section{b. Secara Khusus}

Sebagaimana telah dijelaskan sebelumnya bahwa persyaratan yang berbeda diberikan bagi narapidana tindak pidana khusus. Bagi narapidana tindak pidana khusus selain harus memenuhi persyaratan kelengkapan dokumen sebagaimana kelengkapan dokumen untuk narapidana tindak pidana umum, maka harus pula melengkapi persyaratan berikut:

1. Bagi Narapidana yang melakukan tindak pidana terorisme selain harus melengkapi dokumen sebagaimana narapidana tindak pidana umum, harus juga melengkapi surat keterangan telah mengikuti Program Deradikalisasi dari Kepala Lapas dan/atau kepala Badan Nasional Penanggulangan Terorisme.

2. Bagi Narapidana warga negara asing selain memenuhi kelengkapan dokumen sebagaimana narapidana tindak pidana umum, harus juga melengkapi dokumen:

a. Surat jaminan tidak melarikann diri dan akan menaati persyaratan yang telah ditentukan dari:

1. kedutaan besar/konsulat negara; dan

2. keluarga, orang, atau korporasi yang bertanggung jawab atas keberadaan dan kegiatan Narapidana selama berada di wilayah Indonesia.

b. Surat keterangan dari Direktur jenderal Imigrasi atau Pejabat Imigrasi yang ditunjuk yang menyatakan bahwa yang bersangkutan dibebaskan dari kewajiban memiliki izin tinggal.

3. Surat keterangan sebagaimana dimaksud pada point 2 huruf $b$ diajukan oleh Direktur Jenderal Pemasyarakatan kepada Direktur Jenderal Imigrasi.

\section{Prosedur Asimilasi}

Mengenai tata cara atau lebih dikenal dengan prosedur pemberian asimilasi bagi Narapidana diatur dalam Paragraf 2 Pasal 26 dan Pasal 27 Permen No. 21 Tahun 2013. Pasal 26 dan Pasal 27 mengatur tentang prosedur bagi narapidana tindak pidana umum dan Pasal 28 dan Pasal 29 mengatur prosedur bagi narapidana tindak pidana khusus. Untuk lebih mudah dalam memahami prosedur tersebut maka penulis akan membagi ke dalam dua bagian. Pertama; Prosedur Asimilasi Secara Umum. Kedua; Prosedur asimilasi Secara Khusus. 


\section{a. Prosedur Asimilasi Secara Umum;}

Prosedur ini berlaku untuk narapidana tindak pidana umum. Prosedur awal dalam asimilasi narapidana (Pasal 26) yaitu:

1) Petugas pemasyarakatan mendata Narapidana yang telah memenuhi syarat sebagaimana dimaksud dalam "Syarat Asimilasi Secara Umum” diatas.

2) Pendataan sebagaimana dimaksud pada angka (1) dilakukan terhadap syarat pemberian Asimilasi dan kelengkapan dokumen. yaitu:

Prosedur selanjutnya (Pasal 27)

1) TPP Lapas merekomendasikan usulan pemberian Asimilasi kepada Kepala Lapas berdasarkan data Narapidana dan Anak Didik Pemasyarakatan yang telah memenuhi syarat;

2) Kepala Lapas menetapkan pemberian Asimilasi sebagaimana dimaksud pada pada huruf a, berdasarkan rekomendasi TPP Lapas.

3) Dalam hal asimilasi dilaksanakan secara mandiri dan/atau dengan pihak ketiga, kepala Lapas menetapkan pemberian Asimilasi setelah mendapatkan persetujuan Kepala Kantor Wilayah.

4) Dalam hal Asimilasi yang dilaksanakan dengan penempatan pada Lapas Terbuka, Kepala Kantor Wilayah menetapkan pemberian Asimilasi berdasarkan usulan sebagaimana dimaksud pada huruf a.

5) Persetujuan sebagaimana dimaksud pada huruf c dan pemberian Asimilasi sebagaimana dimaksud huruf $d$ berdasarkan rekomendasi TPP Kantor Wilayah.

Bila semua persyaratan tersebut terpenuhi maka dalam pelaksanaanya harus ditentukan bentuk asimilasi yang tepat bagi narapidana. Ketentuan mengenai pelaksanaan asimilasi ini sebagaimana diatur dalam Pasal 30 Permen No. 21
Tahun 2013 berikut:

Pasal 30 menyebutkan;

(1) Asimilasi sebagaimana dimaksud dalam Pasal 21 dilaksanakan dalam bentuk:

a. Kegiatan pendidikan;

b. Latihan keterampilan;

c. Kegiatan kerja sosial;

d. Pembinaan lainnya, dilingkungan masyarakat.

(2) Selain dilaksanakan dalam bentuk sebagaimana dimaksud pada ayat (1), asimilasi juga dilaksanakan secara mandiri dan/atau dengan pihak ketiga.

(3) Asimilasi sebagaimana dimaksud pada ayat (1) dan ayat (2) dapat dilak sanakan pada Lapas Terbuka

Lebih lanjut mengenai pelaksanaan asimilasi dengan pihak ketiga diatur dalam Pasal 31 Permenkumham No. 21 Tahun 2013.

Pasal 31 menyebutkan;

(1) Dalam hal asimilasi dilaksanakan oleh pihak ketiga sebagaimana dimaksud dalam Pasal 30 ayat (2), harus berdasarkan perjanjian kerjasama.

Perjanjian kerjasama sebagaimana dimaksud pada ayat (1) harus memuat hak dan kewajiban para pihak sesuai dengan ketentuan peraturan perundang-undangan.

\section{b. Prosedur asimilasi Secara Khusus;}

Adapun dikhususkan mengenai Tata Cara Pemberian Asimilasi bagi Narapidana Tindak Pidana Terorisme, Narkotika dan Prekursor Narkotika, Psikotropika, Koupsi, Kejahatan terhadap Keamanan Negara, Kejahatan Hak Asasi Manusia yang Berat, serta Kejahatan Transnasional lainnya yaitu:

Prosedur awal (Pasal 28) yaitu:

1) Petugas pemasyarakatan mendata Narapidana yang telah memenuhi syarat sebagaimana dimaksud 
dalam "syarat Asimilasi Secara Khusus" diatas.

2) Pendataan sebagaimana dimaksud pada angka 1) dilakukan terhadap syarat pemberian Asimilasi dan kelengkapan dokumen.

Bagi narapidana yang memenuhi syarat tersebut maka akan dilakukan pembahasan dalam sidang TPP Lapas. Apabila TPP Lapas telah membuat keputusan mengenai narapidana yang akan diberikan asimilasi, maka prosedur selanjutnya (Pasal 29) yaitu:

1) TPP Lapas merekomendasikan usulan pemberian Asimilasi kepada Kepala Lapas berdasarkan data Narapidana yang telah memenuhi syarat.

2) Kepala Lapas menyampaikan usulan pemberian Asimilasi sebagimana dimaksud pada huruf a kepada Kepala Kantor Wilayah berdasarkan rekomendasi TPP Lapas.

3) Kepala Kantor Wilayah menyampaikan usulan pemberian Asimilasi sebagaimana dimaksud pada huruf $b$ kepada Direktur Jenderal berdasarkan rekomendasi TPP Kantor Wilayah.

4) Direktur Jenderal menyampaikan pertimbangan pemberian Asimilasi kepada Menteri berdasarkan rekomendasi TPP Direktorat Jenderal dan rekomendasi dari instansi terkait untuk mendapatkan persetujuan.

5) Rekomendasi dari instansi terkait sebagaimana dimaksud pada huruf d, yakni:

a) Kepolisian Negara Republik Indonesia, Badan Nasional Penanggulangan Terorisme, dan/atau Kejaksaan Agung dalam hal Narapidana dipidana karena melakukan tindak pidana terorisme, jekahatan terhadap keamanan negara, kejahatan hak asasi manusia yang berat, dan/atau kejahatan transnasional terorganisasi lainnya;

b) Kepolisian Negara Republik Indonesia, Badan Narkotika Nasional, dan/atau Kejaksaan Agung dalam hal Narapidana dipidana karena melakukan tindak pidana narkotika dan prekursor narkotika, psikotropika; dan

c) Kepolisian Negara Republik Indonesia, Kejaksaan Agung dan/atau Komisi Pemberantasan Korupsi dalam hal Narapidana dipidana karena melakukan tindak pidana korupsi.

6) Persetujuan pemberian Asimilasi sebagaimana dimaksud pada huruf d ditetapkan dengan Keputusan Menteri.

Bila semua persyaratan tersebut terpenuhi sebagaimana narapidana tindak pidana umum, maka dalam pelaksanaanya harus ditentukan bentuk asimilasi yang tepat bagi narapidana. Ketentuan mengenai pelaksanaan asimilasi ini sebagaimana diatur dalam Pasal 34 Permen No. 21 Tahun 2013.

Pasal 34 berbunyi:

(1) Bagi Narapidana tindak pidana terorisme, narkotika, dan prekursor narkotika, psikotropika, korupsi, kejahatan terhadap keamanan negara dan kejahatan hak asasi manusia yang berat, serta kejahatan transnasional terorganisasi lainnya, Asimilasi dilaksanakan dalam bentuk kerja sosial pada lembaga sosial.

(2) Lembaga sosial sebagaimana dimaksud pada ayat (1) merupakan lembaga pemerintah atau lembaga yang dibentuk oleh masyarakat yang bergerak di bidang:
a. Agama;
b. Pertanian;
c. Pendidikan dan kebudayaan;
d. Kesehatan; 
e. Kemanusiaan;

f. Kebersihan; dan

g. Yang berorientasi untuk memberikan pelayanan kepada masyarakat

(3) Bentuk kerja sosial disesuaikan dengan bidang lembaga sosial sebagaimana dimaksud pada ayat (2).

(4) Demi kepentingan keamanan, Asimilasi bagi Narapidana yang melakukan tindak pidana terorisme, narkotika dan prekursor narkotika, psikotropika, korupsi, kejahatan terhadap keamanan negara dan kejahatan hak asasi manusia yang berat, serta kejahatan transnasional terorganisasi lainnya dapat tidak dilaksanakan.

\section{KESIMPULAN}

Syarat pemberian asimilasi bagi narapidana tidaklah sama namun dibedakan berdasarkan tindak pidana yang dilakukan. Tindak pidana tersebut dibedakan menjadi 2 (dua) yaitu tindak pidana umum dan tindak pidana khusus. Secara umum syarat asimilasi yaitu:

a. Berkelakuan baik;

b. Aktif mengikuti program pembinaan dengan baik;

c. Telah menjalani $1 / 2$ (setengah) masa pidana.

d. Telah membayar lunas denda dan/ atau uang pengganti (Bagi Yang ada denda dan/atau uang pengganti).

Namun bagi narapidana tindak pidana khusus (tindak pidana terorisme, narkotika dan prekursor narkotika, psikotropika, korupsi, kejahatan terhadap keamanan negara dan kejahatan hak asasi manusia yang berat, serta kejahatan transnasional terorganisir lainnya) selain harus memenuhi persyaratan tersebut maka harus pula memenuhi persyaratan lain yaitu: a. Telah menjalani $2 / 3$ (dua per tiga) masa pidana;

b. Selesai mengikuti program Deradikalisasi bagi Narapidana Terorisme;

c. Menyatakan secara tertulis ikrar kesetiaan kepada NKRI bagi Narapidana Terorisme berkebangsaan Indonesia dan;

d. Menyatakan ikrar secara tertulis untuk tidak mengulangi tindak pidana terorisme bagi Narapidana Terorisme berkebangsaan asing.

Pembedaan persyaratan tersebut tentunya dilakukan untuk lebih mematangkan pembinaan narapidana utamanya pembinaan kepribadian sehingga dalam proses asimilasi narapidana tersebut telah benar-benar siap untuk berinteraksi dan berbaur dengan masyarakat sekitar. Setelah memenuhi persyaratan-persyaratan tersebut barulah selanjutnya dapat diproses untuk diusulkan program asimilasi sebagaimana Permen No. 21 Tahun 2013.

\section{DAFTAR PUSTAKA}

\section{A. Buku-buku}

Didin Sudirman, Sosiologi Penjara; Buku Materi Kuliah Akademi Ilmu Pemasyarakatan, Jakarta, 2003.

I Gede Widhiana Suarda, Hukum Pidana: Materi Penghapus, Peringan dan Pemberat Pidana, Cetakan Ke-2, Bayumedia Publishing, Malang, 2012.

Leden Marpaung, Asas - Teori Praktik Hukum Pidana, Cetakan Ke-6, Sinar Grafika, Jakarta, 2009.

Petrus Irwan Panjaitan dan Chairijah, Pidana Penjara Dalam Perspektif Penegak Hukum, 
Masyarakat dan Naraidana, IHC, Jakarta, 2008.

Sahardjo., 1964, Pohon Beringin Pengayoman, Bandung, Sukamiskin.

\section{B. Jurnal/Disertasi/Majalah}

Napi Craft 2013 Terampil dan Berhasil, Warta Pemasyarakatan Nomor: 55 Tahun XIV/2013.

\section{Internet}

Hamid Awaludin, dalam kata sambutan peresmian LAPAS Terbuka Jakarta, Dikutip dari http://www. Kompas.co.id/news/16/05/06, Diakses pada Tanggal $11 \mathrm{Mei}$ 2016.

Tholib, Pemberdayaan Lapas Terbuka Sebagai Wujud Pelaksanaan Community Based Corrections Di Indonesia, Dikutip dari http://www.ditjenpas.go.id, Diakses pada Tanggal $11 \mathrm{Mei}$ 